American Journal of Applied Sciences 7 (3): 415-419, 2010

ISSN 1546-9239

(C) 2010Science Publications

\title{
To Investigation the Relationship between Monetary, Fiscal Policy and Economic Growth in Iran: Autoregressive Distributed Lag Approach to Cointegration
}

\author{
Anvar Khosravi and Mohammad Sharif Karimi \\ Department of Economics, Faculty of Social Science, Azad University of Sanandaj, Iran
}

\begin{abstract}
Problem statement: It is important for policy makers to find affect of monetary and fiscal policy on economic growth and to know how those impacts on growth to present a effective policies. Approach: We apply the bounds testing (ARDL) approach and to cointegration which is more appropriate for estimation in small sample studies. The data span for the study is from 1960-2006, the empirical results found a cointegration relations between Growth, monetary policy and fiscal policy in Iran. Results: The results indicated the impact of Exchange rate and inflation on growth was negative, government expenditure was found to have significant positive impact on growth. Conclusion: According to results for a sustainable economic growth in Iran, policy makers must try to decrease inflation rate and exchange rate also to find an equilibrium point for government expenditure in futures.
\end{abstract}

Key words: Iran, monetary policy, fiscal policy, growth, ARDL cointegration

\section{INTRODUCTION}

Economic growth has received much attention among economists. Classical studies estimate that economic growth is largely linked to labor and capital as factors of production. The emergence of the endogenous growth theory has encouraged specialists to question the role of other factors in explaining the economic growth phenomenon. In particular, fiscal and monetary policies are considered as an important variable which may determine changes in national income in developed as well as developing countries (Barro, 1991; Barro and Sala-i-Martin, 1991; Levine, 1999). Economists and other analysts generally agree that fiscal and monetary policy actions taken by the policy makers has an important impact on the economy. On the other hand over the past decade, Iranian economy has experienced an unstable conditions such as high inflation, high rate of unemployment due to variety monetary and fiscal policy, Therefore, this study investigates the effect those policies on economic growth (Barro, 1997; Tranzi, 1980).

Literature review: Fiscal and monetary policy is generally believed to be associated with growth, or more precisely, it is held that appropriate fiscal measures in particular circumstances can be used to stimulate economic development or growth (Barro, 1991; Barro and Sala-i-Martin, 1991).
In general, government's expenditure can have positive impact on growth through two main channels: Through increasing the quantity of factors of production and thus causing increase in output growth (Baron, 1976). Indirectly through increasing marginal productivity of privately supplied factors of production (Barro and Sala-i-Martin, 1991). However, is should kept in mind that public expenditures such as investments in infrastructure have diminishing marginal returns, thus there is an optimal ratio of governmental over private spending beyond which public expenditures become inefficient (Fischer, 1977).

Empirical evidence linking public expenditures and growth is, to some degree mixed. Generally, the empirical literature finds an inverse relationship between government spending and growth (Barro and Sala-i-Martin, 1991; Fischer, 1977; Devarajan et al., 1996). But there seems to be a positive relationship between the increase in expenditure (i.e., change) and the growth rate (Barro, 1999; Mishkin, 1982).

Fiscal policy aiming at stimulating growth through increased spending rests on the assumption that government's spending will stimulate private sector spending and thus induce growth through the multiplier effect. The Keynesian view, resting on the belief that propensity to consume increases with income but at a lower rate (hence the multiplier effect through increased savings), holds that the larger is the increase in consumption, the larger the multiplier. This assumes

Corresponding Author: Anvar Khosravi, Department of Economics, Faculty of Social Science, Azad University of Sanandaj, Iran Tel: 0098-871-6626646 Fax: 0098-871-6626458 
Am. J. Applied Sci., 7 (3): 415-419, 2010

price rigidity and excess capacity, which together imply that aggregate demand determines outcome. In the Keynesian theory fiscal expansion, therefore, has a multiplier effect on aggregate demand and hence on outcome. Furthermore, the Keynesian theory implies that the multiplier is greater than one (i.e., marginal propensity to save is greater than marginal propensity to consume) and it is larger for spending increase then for tax reductions (Barro, 1999; Wogin, 1980). However, fiscal expansions can have a negative feedback on output through crowding-out due to induced changed in interest rates and the exchange rate. The stronger is the negative effect of interest rates on investment, the higher will be the (indirect) negative effect of fiscal expansion (through increased borrowing that raises interest rates) on investment (Levine, 1999).

When international exchange is considered (i.e., in an open economy model), there might be additional crowding-out through appreciation of the exchange rate that is due to increased capital inflows induced through higher interest rates. Subsequently, the external current account deteriorates which offsets the increase in domestic demand induced by fiscal expansion. Both of these effects will have negative consequences for growth under the assumptions of a positive causal effect of investment on growth and will be stronger the stronger is the negative effect of interest rates on investment. On the other hand, the crowding-out effect will be smaller the larger is the dependence of investment on income. In addition, crowding out will be smaller the smaller is the dependence of money demand on interest rates and the greater is its dependence on income.

In this context, the relationship between the exchange rate and prices is particularly important. The extend of crowding-out with flexible exchange rate will be smaller the greater is the response of domestic prices to the exchange rate since the appreciation of the exchange rate will then lower domestic prices.

Barro (1991); Engen and Skinner (1996) and Fischer (1977) have investigated the impact of monetary policy actions on nominal GNP which measures aggregate spending on goods and services by households, businesses, government and foreigners-because it is generally believed that policy actions affect the economy primarily by influencing aggregate spending.

Aggregate spending, in turn, directly affects the production of goods and services and the unemployment and inflation rates. Thus, the primary goal of monetary policy is to achieve GNP growth that is consistent with the ultimate objectives of monetary policy-high employment, economic growth, price stability and a sustainable pattern of international transactions (Barro, 1999).

The theoretical studies of (Fischer, 1977; Wogin, 1980) on the other hand, conclude that anticipated monetary policy influences real economic variables at least in the short-run because of the rigidities in wage and price contracts.

Mishkin (1982), employed a somewhat different methodology and found no evidence that anticipated monetary policy does not influence real economic activity.

\section{MATERIALS AND METHODS}

Econometric methodology: This study discusses the properties of time series and the econometric methodology used to examination of monetary policy and fiscal policy and growth in Iran.

ARDL model specification: To empirically analyze the long-run relationships and dynamic interactions among the variables of interest, the model has been estimated by using the bounds testing (or Autoregressive Distributed Lag (ARDL)) cointegration. The procedure is adopted for the following three reasons. Firstly, the bounds test procedure is simple. As opposed to other multivariate cointegration techniques such as Johansen and Juselius (1990). It allows the cointegration relationship to be estimated by OLS once the lag order of the model is identified. Secondly, the bounds testing procedure does not require the pretesting of the variables included in the model for unit roots unlike other techniques such as the Johansen approach. It is applicable irrespective of whether the regressors in the model are purely $\mathrm{I}(0)$, purely $\mathrm{I}(1)$ or mutually cointegrated. Thirdly, the test is relatively more efficient in small or finite sample data sizes as is the case in this study. The procedure will however crash in the presence of I (2) series.

Bounds testing approach: The newly Autoregressive Distributed Lag (ARDL) bound test proposed by Pesaran et al. (2001); Pesaran and Pesaran (1997). Is used to estimate the import demand model? One of the advantages of using ARDL bounds test is that it is applicable regardless of the stationary properties or irrespective of whether the regressors are purely $\mathrm{I}(0)$ or I(1), or mutually cointegrated. This proposes a useful approach that bypasses the need for pre-testing the integration order of variables which the potential biased associated in the unit root test can be avoided8. Moreover, the bounds test approach is robust for cointegration analyses with small sample study 
(Pesaran et al., 2001). According to the bounds test procedure, is essential to model Eq. 6 as a conditional ARDL as follows:

$$
\begin{aligned}
& \Delta \mathrm{LnGDP}=\theta_{\circ}+\delta_{1} \operatorname{LnGDP}_{\mathrm{t}-1}+\delta_{2} \mathrm{LnCPI}_{\mathrm{t}-1} \\
& +\delta_{3} \mathrm{LnG}_{\mathrm{t}-1}+\delta_{4} \mathrm{LnM}_{1 \mathrm{t}-1}+\delta_{5} \mathrm{LnEXCH}_{\mathrm{t}-1} \\
& +\sum_{\mathrm{i}=1}^{\mathrm{n}} \lambda_{1} \Delta \mathrm{LnGDP}_{\mathrm{t}-1}+\sum_{\mathrm{i}=0}^{\mathrm{n}} \lambda_{2} \Delta \mathrm{LnCPI}_{\mathrm{t}-1}+ \\
& \sum_{\mathrm{i}=0}^{\mathrm{n}} \lambda_{3} \Delta \mathrm{LnG}_{\mathrm{t}-1}+\sum_{\mathrm{i}=0}^{\mathrm{n}} \lambda_{4} \Delta \operatorname{LnM}_{\mathrm{t}-1}+\sum_{\mathrm{i}=0}^{\mathrm{n}} \lambda_{5} \Delta \mathrm{L}_{\mathrm{n}} \mathrm{EXCH}_{\mathrm{t}-1}+\varepsilon_{\mathrm{t}}
\end{aligned}
$$

Where:

$$
\begin{array}{ll}
\text { GDP } & =\text { Gross Domestic Product } \\
\mathrm{CPI} & =\text { Consumer Price Index } \\
\mathrm{M} 1 & =\text { Money stock } \\
\mathrm{G} & =\text { Government expenditure } \\
\mathrm{EXCH} & =\text { Exchange rate } \\
\Delta & =\text { First difference operator } \\
\varepsilon_{\mathrm{t}} & =\text { A white-noise disturbance error term }
\end{array}
$$

The long-run relationship between the concerned variables can be conducted based on the Wald test (Fstatistic) by imposing restrictions on the estimated longrun coefficients of one period lagged level of the variables equal to zero, that is, Ho: $\delta 1=\delta 2=\delta 3=\delta 4=$ $\delta 5=0$. Then, the computed F-statistic is compared to the critical value tabulated in (Pesaran and Pesaran, 1997; Narayan, 2004). The lower bound values assumed that the explanatory variables $\mathrm{x}_{\mathrm{t}}$ are integrated of order zero, or $\mathrm{I}(0)$, while the upper bound values assumed that $\mathrm{x}_{\mathrm{t}}$ are integrated of order one, or $\mathrm{I}(1)$. Therefore, if computed F-statistic falls below the lower bound value, $\mathrm{I}(0)$, the null hypothesis of no cointegration cannot be rejected. Conversely, if the computed F-statistic exceeds the upper bound value, I(1) then it is concluded that imports and its determinants are moving together to a long-run equilibrium. Besides, if the computed F-statistic falls within the bound values, a conclusive inference cannot be made (Shrestha and Chowdhury, 2005).

Once a cointegration relationship has been ascertained, the long-run and short-run parameters of the cointegration equation are then estimated. The longrun cointegration relationship is estimated using the following specification:

$$
\begin{aligned}
\operatorname{LnGDP} & \theta_{\circ}+\delta_{1} \operatorname{LnGDP}_{\mathrm{t}-1}+\delta_{2} \operatorname{LnCPI}_{\mathrm{t}-1} \\
& +\delta_{3} \mathrm{LnG}_{\mathrm{t}-1}+\delta_{4} \mathrm{LnM}_{1 \mathrm{t}-1} \\
& +\delta_{5} \mathrm{LnEXCH}_{\mathrm{t}-1}+\varepsilon_{\mathrm{t}}
\end{aligned}
$$

However, due to the speed of adjustment back to equilibrium may not immediately adjust, the demand for imports is most likely to be varied from its actual level of imports. This could be caused by the adjustment process and lags in perceiving changes in any of the imports' determinants. Hence, the speed of adjustment of the imports demand model can be captured through the estimation of the error correction model as expressed below:

$$
\begin{aligned}
\Delta \mathrm{LnGDP}_{=} & \theta_{\circ}+\sum_{\mathrm{i}=1}^{\mathrm{n}} \lambda_{1} \Delta \operatorname{LnGDP}_{\mathrm{t}-1}+\sum_{\mathrm{i}=0}^{\mathrm{n}} \lambda_{2} \Delta \mathrm{LnCPI}_{\mathrm{t}-1} \\
& +\sum_{\mathrm{i}=0}^{\mathrm{n}} \lambda_{3} \Delta \mathrm{LnG}_{\mathrm{t}-1}+\sum_{\mathrm{i}=0}^{\mathrm{n}} \lambda_{4} \Delta \mathrm{LnM}_{\mathrm{t}-1} \\
& +\sum_{\mathrm{i}=0}^{\mathrm{n}} \lambda_{5} \Delta \mathrm{L}_{\mathrm{n}} \mathrm{EXCH}_{\mathrm{t}-1}+\lambda_{6} \varepsilon_{\mathrm{t}-1}+\varepsilon_{\mathrm{t}}
\end{aligned}
$$

where, $\varepsilon_{\mathrm{t}-1}$ the error correction term of one period lagged estimated from the Eq. 3 while the coefficient $\lambda$ measures the speed of adjustment of the model's convergence to equilibrium.

Sources of data: This study employed annually data that covers the period from 1960-2005 for the case of Iran. The data is primarily gathered from various issues of Central bank of Iran that included exchange rates (Rial/USD), government consumption and consumer price index.

\section{RESULTS AND DISCUSSION}

Table 1 shows the results of ADF unit root tests. The results clearly show that all variables tend to be nonstationary at level. The ADF test failed to reject the null hypothesis of nonstationary. At first difference level, the ADF test has well rejected the null hypothesis of unit root at $1 \%$ significant level This implies that these variables are integrated of order one or I(1), suggesting the existence of cointegrating relationships among the series of Variables.

Table 1: Result of unit root tests

\begin{tabular}{lllll}
\multicolumn{5}{l}{ Table 1: Result of unit root tests } \\
\hline & \multicolumn{4}{l}{ MacKinnon critical value $(\%)$} \\
Variable & ADF & 1 & 5 & \\
\hline LG & $-2 / 457397$ & $-4 / 175640$ & $-3 / 513075$ & $-3 / 186854$ \\
D (LG) & $-11 / 12639$ & $-4 / 175640$ & $-3 / 513075$ & $-3 / 186854$ \\
LCPI & $0 / 52771$ & $-3 / 581152$ & $-2 / 926622$ & $-2 / 601424$ \\
D (LCPI) & $-7 / 233593$ & $-3 / 588509$ & $-2 / 929734$ & $-2 / 603064$ \\
LEXCH & $-2 / 087403$ & $-4 / 165756$ & $-3 / 508508$ & $-3 / 184230$ \\
D (LEXCH) & $-5 / 203316$ & $-4 / 170583$ & $-3 / 51074$ & $-3 / 185512$ \\
LGDP & $-2 / 177456$ & $-4 / 170583$ & $-3 / 51074$ & $-3 / 185512$ \\
D (LGDP) & $-3 / 759120$ & $-4 / 170583$ & $-3 / 51074$ & $-3 / 185512$ \\
LM1 & $-2 / 506249$ & $-4 / 170583$ & $-3 / 510740$ & $-3 / 185512$ \\
D (LM1) & $-8 / 714935$ & $-4 / 17564$ & $-3 / 513075$ & $-3 / 18654$ \\
\hline
\end{tabular}


Am. J. Applied Sci., 7 (3): 415-419, 2010

Table 2: Result of Johansen and Juselius (1990) cointegration test The optimal lag $=1$

\begin{tabular}{lllll} 
Probability & Critical value 5\% & Trace statistic & $\left(\mathrm{H}_{1}\right)$ & $\left(\mathrm{H}_{0}\right)$ \\
\hline $0 / 0189^{*}$ & $69 / 81889$ & $74 / 79965^{*}$ & $\mathrm{r}=1$ & $\mathrm{r}=0$ \\
$0 / 2858$ & $47 / 85613$ & $38 / 37713$ & $\mathrm{r}=2$ & $\mathrm{r}<1$ \\
$0 / 5721$ & $29 / 79707$ & $17 / 91854$ & $\mathrm{r}=3$ & $\mathrm{r}<2$ \\
$0 / 6918$ & $15 / 49471$ & $6 / 032173$ & $\mathrm{r}=4$ & $\mathrm{r}<3$ \\
$0 / 8226$ & $3 / 841466$ & $0 / 050279$ & $\mathrm{r}=5$ & $\mathrm{r}<4$ \\
\hline
\end{tabular}

Note: $r$ indicates the number of cointegrating vectors. The $(*)$ denotes that rejection at the $5 \%$ critical value. The statistics are computed with linear trend in the VAR equation

Table 3: Results of ARDL bounds test

\begin{tabular}{lcccccc}
\hline & $90 \%$ & & $95 \%$ & & $99 \%$ & \\
& - & & & & \\
& & & & & \\
9\247298 F-statistic & $\mathrm{I}(0)$ & $\mathrm{I}(1)$ & $\mathrm{I}(0)$ & $\mathrm{I}(1)$ & $\mathrm{I}(0)$ & $\mathrm{I}(1)$ \\
\hline Critical value & & & & & & \\
Pesaran et al. (2001) & $2 \backslash 45$ & $3 \backslash 52$ & $2 \backslash 86$ & $4 \backslash 01$ & $2 \backslash 86$ & $4 \backslash 01$ \\
Narayan (2004) & $2 \backslash 75$ & $3 \backslash 99$ & $3 \backslash 35$ & $4 \backslash 77$ & $3 \backslash 35$ & $4 \backslash 77$
\end{tabular}

Note: Critical values are extracted based on Pesaran et al. (2001); Narayan (2004)

Table 4: Results of long-run relationship

\begin{tabular}{llll}
\hline Variables & Coefficients & Standard error & T- satatistic \\
\hline C & $6 / 37742$ & $0 / 817618$ & $8 / 240702^{*}$ \\
LG & $0 / 579119$ & $0 / 106839$ & $5 / 417743^{*}$ \\
LEXCH & $-0 / 177421$ & $0 / 060472$ & $-2 / 933939^{* *}$ \\
LCPI & $-0 / 435507$ & $0 / 095644$ & $-4 / 553419^{*}$ \\
LM1 & $-0 / 124567$ & $0 / 098205$ & $-1 / 268439$ \\
\hline
\end{tabular}

Note: The asterisks $(*)$ and $(* *)$ denote the statistically significant at 1 and $5 \%$ levels respectively

Given each of the series is considered to be I(1) process, the Johansen multivariate cointegration is subsequently designed to scrutinize the existence of cointegration relationship between variables. The estimated results show that the null hypothesis of noncointgerating vector is rejected at $1 \%$ significant level as reported in Table 2. This indicates the presence of one cointegration relationship for equilibrium model, suggesting a long run equilibrium relationship among exchange rate $(\mathrm{LEXCH})$, government expenditure (LG), Inflation (LCPI), Growth (1G) and money stock (LM1).

The results of ARDL bounds testing to cointegration test in Table 3 indicate that the restricted null hypothesis of the long-run coefficient is rejected (Ho: $\delta 1=\delta 2=\delta 3=\delta 4=\delta 5=0$ ) at 1 percent significant level. This suggests that in Iran there is a cointegration relationship between exchange rate, government expenditure, Inflation, growth and money stock.

The discussions of long-run relationship for variables are based on the data in Table 4. The estimated coefficients of the long-run relationship show that government expenditure has a very high significant impact on GDP growth). A $1 \%$ increase in capital investment leads to approximately $0.57 \%$ increase in GDP.
Table 5: Error correction representation for the selected ARDL model

\begin{tabular}{llll}
\hline Variables & Coefficients & Standard error & T-satatistic \\
\hline $\mathrm{C}$ & $0 / 353552$ & $0 / 095410$ & $3 / 705599^{*}$ \\
$\Delta \mathrm{LM}_{1}$ & $-0 / 079493$ & $0 / 102668$ & $-0 / 774272$ \\
$\Delta \mathrm{LG}$ & $0 / 274384$ & $0 / 083483$ & $3 / 286694$ \\
$\Delta \mathrm{LEXCH}$ & $-0 / 065886$ & $0 / 048848$ & $-1 / 348801$ \\
$\Delta \mathrm{LCPI}$ & $-0 / 011399$ & $0 / 118664$ & $-0 / 096061$ \\
ECM $(-1)$ & $-0 / 295667$ & $0 / 096643$ & $-3 / 059366^{*}$ \\
\hline
\end{tabular}

The inflation and exchange rate variables have a negatively signed. This is indicative that increase of inflation and exchange rate should decrease economic growth in Iran. Considering the impact of money stock, it is not statically significant with wrong signed. Therefore, this variable has not a direct effect on GDP in Iranian economy so that must consider on indirect effect of this variable on GDP in Iran. The results of the short-run dynamic coefficients associated with the longrun relationships obtained from the ECM Eq. 3 are given in Table 5. The signs of the short-run dynamic impacts are maintained to the long-run. The Equilibrium Correction coefficient (ECM), estimated$0.29(0.0966)$ is highly significant, has the correct sign and imply a fairly slow speed of adjustment to equilibrium after a shock. Approximately 29\% of disequilibria from the previous year's shock converge back to the long-run equilibrium in the current year.

\section{CONCLUSION}

The purpose of this study was to test the relationship between fiscal and monetary policy and economic growth in Iran. This study has employed the bounds testing (ARDL) approach to cointegration to examine the long run and short run relationships between fiscal policy, monetary policy and economic growth using Iran as the case study. The results show that there is a cointegration relationship between exchange rate, government expenditure, Inflation, growth and money stock. The results also indicate government expenditure (as Fiscal policy) has a very high significant impact on GDP growth. Meanwhile, the inflation and exchange rate (as monetary policy) variables have a negatively signed on GDP. The empirical evidence from Iran does not support impact of money stock (as an important proxy for monetary policy) on GDP. However, it should have indirect relationship on GDP. The associated equilibrium correction was also significant confirming the existence of long-run relationships. The equilibrium correction is fairly slow and is restored by the third quarter of the year.

\section{REFERENCES}

Baron, D.P., 1976. Fluctuating exchange rates and the pricing of exports. Econ. Enquiry, 14: 425-438. 
Barro, R.J., 1997. Macroeconomics. 1st Edn., The MIT Press, New York, pp: 867.

Barro, R.G., 1991. Economic growth in a cross section of countries. Q. J. Econ., 106: 407-444.

Barro, R.G., 1999. Notes on growth accounting. J. Econ. Growth, 4: 119-137.

Barro, R.J. and X. Sala-i-Martin, 1991. Convergence across states and regions. Brook. Papers Econ. Activ., 1: 107-182.

Devarajan, S., V. Swaroop and H. Zou, 1996. The composition of public expenditure and economic growth. J. Monetary Econ., 37: 313-344.

Fischer, S., 1977. Long term contracts. Rational expectations and the optimal money supply rule. J. Politic. Econ., 85: 191-206.

Engen, E. and J. Skinner, 1996. Taxation and economic growth. Natl. Tax J., 49: 617-642.

Levine, R., 1999. Law finance and economic growth. J. Fin. Intermediat. 8: 8-35.

Johansen, S. and K. Juselius, 1990. Maximum likelihood estimation and inference on cointegration-with application to the demand for money. Oxf. Bull. Econ. Stat., 52: 169-210.
Mishkin, F.S., 1982. Does anticipated monetary policy matter? An econometric investigation. J. Politic. Econ., 90: 22-51.

Narayan, P.K., 2004. Fiji's tourism demand: The ARDL approach to cointegration. Tourism Econ., 10: 193-206.

Pesaran, M.H. and B. Pesaran, 1997. Working with Microfit 4.0: Interactive Econometric Analysis. Oxford University Press, Oxford, pp: 505.

Pesaran, M.H., Y. Shin and R.J. Smith, 2001. Bounds testing approaches to the analysis of level relationships. J. Applied Economet., 16: 289-326.

Shrestha, M.B. and K. Chowdhury, 2005. ARDL modeling approach to testing the financial liberalization hypothesis. Economics Working Paper Series 2005, University of Wollongong.

Tranzi, V., 1980. The underground economy in the United States: Estimates and implications. Banca Nazionale del Lavoro, 135: 427-453.

Wogin, G., 1980. Unemployment and monetary policy under rational expectations. J. Monetary Econ., 6: 59-68. 